\title{
Trace element concentrations in the grain of wheat cultivars as affected by nitrogen fertilization
}

\author{
Zlatko Svečnjakk, ${ }^{a}$, Marina Jenel ${ }^{b}$, Marija Bujan ${ }^{a}$, Dubravka Vitalib and Irena Vedrina Dragojevićb \\ a University of Zagreb Faculty of Agriculture, Svetošimunska 25, 10000 Zagreb, Croatia \\ b University of Zagreb Faculty of Pharmacy and Biochemistry, Ante Kovačića 1, 10000 Zagreb, Croatia \\ e-mail: svecnjak@agr.hr
}

\begin{abstract}
Three winter wheat cultivars were grown under low-N and high-N fertilization rates over two growing seasons. In spite of smaller 1000-grain weight, the high- $\mathrm{N}$ fertilization produced higher grain yields as well as grain $\mathrm{N}$ and trace element concentrations in both growing seasons. Trace element increments with high- $\mathrm{N}$ rate averaged $14.0 \%$ for $\mathrm{Fe}, 9.2 \%$ for $\mathrm{Zn}, 19.7 \%$ for $\mathrm{Mn}, 13.2 \%$ for $\mathrm{Cu}, 15.1 \%$ for $\mathrm{Ni}$, and $23.0 \%$ for $\mathrm{Cd}$. Only Na concentration was unaffected by $\mathrm{N}$ fertilization, whereas $\mathrm{Pb}$ and $\mathrm{Cr}$ were below detection limits. Absolutely small, but significant differences existed among tested cultivars for all trace elements and these cultivar effects were uniform on both $\mathrm{N}$ fertilization rates. However, cultivars differed in their rankings for trace element concentrations across two growing seasons and these specific responses appeared to be closely related to grain $\mathrm{N}$.
\end{abstract}

Key words: 1000-grain weight, grain N, growing season, winter wheat, yield

\section{Introduction}

Wheat (Triticum aestivum L.) grain is a staple food worldwide and a primary source of carbohydrates, proteins, and minerals. Nutritional quality of wheat grain, including its trace element status is of interest for both agronomists and nutritionists. Concentrations of iron $(\mathrm{Fe})$ and zinc $(\mathrm{Zn})$ in wheat grain have received particular attention due to the widespread deficiency of these trace elements in humans (Welch \& Graham 2004). Despite having poor concentrations of trace elements in grain, wheat based products may supply important daily intake. The United States Department of Agriculture food consumption survey estimates that grain products provide $33 \%$ of daily intake for Fe (Burk \& Solomons 1985). Wheat and wheat based products are also important source of manganese (Mn) and significantly contribute to the daily intake of $\mathrm{Zn}$ and chromium (Cr) (Santos et al. 2004). Consequently, cereals are important in different strategies aiming at alleviating micronutrient deficiencies (Brinch-Pedersen et al. 2007). However, metals with unknown biological function such as cadmium $(\mathrm{Cd})$ and lead $(\mathrm{Pb})$ can also be accumulated in plants and their toxic effects on plants as well as on human health are well known (Musa and Abdullahi 2013).

Limited information is available on the effects of nitrogen $(\mathrm{N})$ fertilization and cultivar on trace element concentrations in wheat grain. In Croatia, winter wheat is a major cereal crop with an average grain yield of $4.93 \mathrm{t} \mathrm{ha}^{-1}$ for the last decade (2001-2010). Despite favorable environmental conditions, this relatively low national yield indicate that wheat crop is still widely grown under extensive production systems primarily characterized by suboptimal N fertilization (Varga et al. 2001). There is an increased trend among Croatian farmers toward wheat production under more intensive N fertilization to achieve higher grain yields. However, Syltie \& Dahnke (1983) remarked that wheat yield considerations are economically attractive but may not lead to the superior grain quality for human health. No information is currently available on trace element levels in Croatian wheat despite being a main component in human diet. Moreover, the effects of $\mathrm{N}$ fertilization and cultivar on trace element concentrations are poorly understood.

Numerous monitoring studies have reported on the trace element concentrations of wheat as affected by geographical location and environment, but few studies have reported on the effect of $\mathrm{N}$ fertilization and cultivar. Gawalko et al. (2001) found that soil factors appear to be major controlling influences on the trace elements of the wheat samples collected from various Canadian farmers over three years. McGrath (1985) also found large variations in the nutrient concentrations in a winter wheat grain collected from farms across the United Kingdom (UK) within the same growing season. The concentration of $\mathrm{Fe}, \mathrm{Zn}$, and copper $(\mathrm{Cu})$ varied threefold, whilst $\mathrm{Mn}$ varied by a factor of five. Only the concentrations of $\mathrm{Fe}, \mathrm{Zn}, \mathrm{Cu}$ and $\mathrm{Mn}$ changed significantly as yield increased, 
and most of the changes were positive, except for $\mathrm{Mn}$, which did not increase with higher yield. A half of century ago, Schrenk (1955) reported that mineral composition of winter wheat grain in Kansas varied more for minor elements than the major elements. Recently, it has been documented in a greenhouse experiment that $\mathrm{N}$ nutritional status of the plant is a critical toll for agronomic biofortification of wheat with Zn and Fe (Kutman et al. 2011).

Trace element composition depends primarily on the availability of minerals in the soil to the plants, but different wheat cultivars may absorb different levels from the same soil, and the same cultivar may absorb different amounts of minerals in different soils. Dikeman et al. (1982) collected wheat grain samples from different locations in the Great Plains. Authors demonstrated significant variability in minerals for the same cultivar grown in different locations, although there was greater variability among cultivars grown in the same location. In contrast, McGrath (1985) reported small cultivar differences in grain micronutrient concentrations. Other findings (Syltie \& Dahnke, 1983) indicated that wheat cultivars may differ in their responses to $\mathrm{N}$ fertilization for grain minerals.

The purpose of this study was to determine the effect of $\mathrm{N}$ fertilization on the trace element concentration in the grain of winter wheat cultivars widely grown in Croatia.

\section{Materials and methods}

\section{Field experiments}

Field experiments in a winter wheat-corn (Zea mays L.)-soybean (Glycine max [L.] Merr.) crop rotation were conducted in northwestern Croatia at the Faculty of Agriculture Zagreb experimental field during the 2000-2001 (2001) and 2001-2002 (2002) growing seasons on a silt loam soil (Typic Udifluvents). Monthly mean temperatures and total precipitation during the growing seasons are shown in Table 1.

Table 1. Monthly mean temperature and total precipitation during winter wheat growing seasons 2000-2001 (2001) and 2001-2002 (2002).

\begin{tabular}{ccccc}
\hline & \multicolumn{2}{c}{ Mean temperature ${ }^{\circ} \mathrm{C}$} & \multicolumn{2}{c}{ Total precipitation mm } \\
Month & 2001 & 2002 & 2001 & 2002 \\
\hline October & 13,4 & 14,3 & 92 & 8 \\
November & 9,2 & 3,6 & 109 & 86 \\
December & 4,6 & $-1,6$ & 118 & 24 \\
January & 4,0 & 1,7 & 79 & 22 \\
February & 4,9 & 6,5 & 13 & 47 \\
March & 10,4 & 8,8 & 100 & 33 \\
April & 10,6 & 10,8 & 79 & 131 \\
May & 17,8 & 18,4 & 71 & 86 \\
June & 18,4 & 21,1 & 118 & 71 \\
\hline
\end{tabular}

The experiment was conducted using a split-plot design with five replications. Nitrogen fertilization treatments (low and high) formed 10 main plots. Low-N fertilization rate consisted of $67 \mathrm{~kg} \mathrm{~N} \mathrm{ha}^{-1}$ with $40 \mathrm{~kg} \mathrm{~N} \mathrm{ha}^{-1}$ applied before planting and one topdressing application at growth stage (GS) 24 (Zadoks et al. 1974) with $27 \mathrm{~kg} \mathrm{~N} \mathrm{ha}^{-1}$. High-N fertilization rate (total of $194 \mathrm{~kg} \mathrm{~N} \mathrm{ha}^{-1}$ ) included $86 \mathrm{~kg} \mathrm{~N} \mathrm{ha}^{-1}$ applied before planting and topdressing of $54 \mathrm{~kg} \mathrm{~N} \mathrm{ha}^{-1}$ at GS 22, $27 \mathrm{~kg} \mathrm{~N} \mathrm{ha}^{-1}$ at GS 24, and $27 \mathrm{~kg} \mathrm{~N} \mathrm{ha}^{-1}$ at GS 31. Plots were topdressed on 9 February 2001 and 27 February 2002 for GS 22, 7 March 2001 and 27 March 2002 for GS 24, and 1 April 2001 and 25 April 2002 for GS 31. Subplots consisted of three winter wheat cultivars, namely 'Marija', 'Renan', and 'Žitarka'. Chosen genotypes are widely grown in the winter wheat production systems of Croatia.

Previous crops (corn and soybean) were grown under low $\mathrm{N}$ rates to minimize the effect of residual nitrogen on subsequent winter wheat crop. In October of each year, $500 \mathrm{~kg} \mathrm{ha}^{-1} \mathrm{~N}-\mathrm{P}_{2} \mathrm{O}_{5}-\mathrm{K}_{2} \mathrm{O}$ fertilizer (8:26:26) was broadcast before mouldboard ploughing at $30 \mathrm{~cm}$. Additional urea, $\left(\mathrm{NH}_{2}\right)_{2} \mathrm{CO},(46 \% \mathrm{~N})$ at $100 \mathrm{~kg} \mathrm{ha}^{-1}$ was broadcast before seedbed preparation on plots receiving high $\mathrm{N}$ rate. Cultivars were planted at recommended rate $\left(770 \mathrm{seeds}^{-2}\right)$. At seeding, plots consisted of 10 rows that were $11 \mathrm{~cm}$ apart and $7.0 \mathrm{~m}$ in length. Wheat was planted on $28 \mathrm{Oc}-$ tober 2000 and 17 October 2001 within the optimum planting-date window for the region. Herbicides amido- 
sulfuron and bromoxynil at $225 \mathrm{~g}$ a.i. ha ${ }^{-1}$ were applied at GS 24. Granular N, $27 \%$ ammonium nitrate $\left(\mathrm{NH}_{4} \mathrm{NO}_{3}\right)$, was broadcasted by hand in each topdressing application for the low- $\mathrm{N}$ and high-N fertilization rates. Fungicide tebuconazol ( $250 \mathrm{~g}$ a.i. ha-1) was applied as a foliar spray in $200 \mathrm{I} \mathrm{ha}^{-1}$ water at GS 55 . Plots were harvested by a small-plot combine. Total grain yields are expressed on a kilogram per hectare basis at a $130 \mathrm{~g} \mathrm{~kg}^{-1}$ moisture content. Harvest dates were 5 July 2001 and 4 July 2002. Average 1000-grain weight was determined by counting and weighing two 100-grain samples.

\section{Laboratory analyses}

After harvesting 10-g wheat grain samples were dried in an oven at $80{ }^{\circ} \mathrm{C}$ for 24 hours, ground on a laboratory mill to pass a 20-mesh sieve $(<0.84 \mathrm{~mm})$, mixed thoroughly, and stored in plastic containers at $4{ }^{\circ} \mathrm{C}$ until further analysis. Grain N was determined by the Kjeldhal method (AACC International, 2000) using the semiautomatic Büchi system (Büchi Labortechnik AG Glawil, Switzerland). The method was verified using the phenylalanine as the reference substance immediately prior, during and after conducting the analyses of wheat grain. Trace elements were determined by Inductively Coupled Plasma Atomic Emission Spetrometry (ICP-AES) on a Trace Scan Thermo (Thermo Jarell Ash Corporation, USA) using the standard techniques (JACTS 1995).

Wheat sample preparations for spectrometric analysis were done using standard microwave digestion procedure (Milestone 1996) since it is not time consuming and is free of contamination risk. Briefly, a $900 \mathrm{mg}$ of milled wheat sample was weight directly into digestion vessel, a $65 \% \mathrm{HNO}_{3}(\mathrm{v} / \mathrm{v})(5 \mathrm{ml})$ and $30 \% \mathrm{H}_{2} \mathrm{O}_{2}(\mathrm{v} / \mathrm{v})(2 \mathrm{ml})$ were added, vessels were covered, placed into the rotator body of microwave oven (Milestone MLS 1200 Mega, Milestone, Bergamo, Italy) and digestion program was recalled. After cooling, digested samples were diluted to $50 \mathrm{ml}$ using deionized water, and stored in $50 \mathrm{ml}$ polyethylene flasks until analysis. The occurrence of excessive pressure during the digestion procedure, which represents the main restriction of microwave digestion, was avoided by carefully selecting the duration and power of each digestion step and using the moderate amounts of samples for digestion. All laboratory ware used for trace element determination was previously soaked in $10 \%(\mathrm{v} / \mathrm{v})$ nitric acid for $24 \mathrm{~h}$, rinsed several times with deionized water and dried.

The ICP-AES analyses were conducted in an accredited (ISO/IEC 17025:2005) laboratory. The calibration of ICP-AES was maintained with independent standards using a mixed multicomponent standard at three concentrations. Blanks were treated identically and together with the sample. The analytical wavelengths $(\mathrm{nm})$ for trace elements were 238.2 for Fe, 324.7 for Cu, 206.2 for Zn, 257.6 for Mn, 231.6 for nickel (Ni), 214.4 for Cd, 206.1 for Cr and 220.4 for Pb. Detection limits for the analyzed trace elements were $0.017 \mathrm{mg} \mathrm{kg}^{-1}$ for Fe and $\mathrm{Cu}, 0.010 \mathrm{mg} \mathrm{kg}^{-1}$ for $\mathrm{Zn}, 0.003 \mathrm{mg} \mathrm{kg}^{-1}$ for $\mathrm{Mn}$ and $\mathrm{Cd}, 0.190 \mathrm{mg} \mathrm{kg}^{-1}$ for $\mathrm{Ni}, 0.133 \mathrm{mg} \mathrm{kg}^{-1}$ for $\mathrm{Cr}$ and $0.067 \mathrm{mg} \mathrm{kg}^{-1}$ for Pb. All trace element measurements were carried out in duplicates.

\section{Statistical analyses}

The experiment consisted of two treatment factors: two $\mathrm{N}$ fertilization rates (main plots) and three winter wheat cultivars (split-plots), with five replications. Data were analyzed using mixed model procedures (SAS Institute 1997). Combined analysis of variance was computed with year, $\mathrm{N}$ fertilization rate and cultivar considered fixed effects. Mean differences were assessed using the LSD values if the $F$-test was significant at $p=0.05$. Direct relationships among grain yield, 1000 -grain weight, grain $\mathrm{N}$ and trace element concentrations were analyzed with simple Pearson correlation coefficients.

\section{Results and discussion}

Growing season significantly affected grain yield, 1000-grain weight, grain N, and all trace element concentrations (Table 2). More favorable growing conditions in 2002 (larger precipitation and higher air temperatures in late spring, Table 1) increased grain yields by an average of $24.9 \%$ (1486 kg ha-1) and grain $\mathrm{N}$ by an average of $8.5 \%$ (16 $\mathrm{g} \mathrm{kg}^{-1}$ ) in comparison to the growing season of 2001. Higher grain yields and grain $\mathrm{N}$ content in 2002 were also associated with higher trace element concentrations (Table 3). Compared to 2001, the concentrations of Fe, Zn, Cu, $\mathrm{Ni}$, and $\mathrm{Na}$ in the growing season of 2002 increased by an average of 17.3, 16.5, 16.4, 11.1, and 15\%, respectively, whereas larger increase was found for Mn, which averaged 41.8\%. McGrath (1985) also found that Mn concentration in wheat grain varied the most of all trace elements for samples collected from different farms in the UK survey. In our experiment, Mn concentration had relatively high values in 2002 (59.4 $\mathrm{mg} \mathrm{kg}^{-1}$ on average), which was larger than those commonly observed by other authors. However, Davis et al. (1984) reported a range from 
35 to $65 \mathrm{mg} \mathrm{kg}^{-1}$ for $\mathrm{Mn}$ in 'Centruk' wheat grown in 13 locations and in two crop years in several regions of the United States. Monitoring wheat samples from producers of spring wheat in Canada, Gawalko et al. (2001) found that year to year variations were small for $\mathrm{Zn}$ and $\mathrm{Mn}$, whereas $\mathrm{Cu}$ and Fe content showed 12 and $9 \%$ decreases, respectively, over the three year period. In our research, $\mathrm{Cd}$ concentration in wheat grain had the largest variation (51.8\% on average) over two growing seasons (Table 3). However, $\mathrm{Cd}$ concentrations even in the growing season of 2002 were still much smaller than the European Community limit $\left(0.2 \mathrm{mg} \mathrm{kg}^{-1}\right)$ for $\mathrm{Cd}$. Chromium and $\mathrm{Pb}$ concentrations in all grain samples were both below detection limit.

Table 2. Combined analysis of variance for grain yield, 1000-grain weight, nitrogen $(\mathrm{N})$ and trace element concentrations of wheat grain.

\begin{tabular}{|c|c|c|c|c|c|c|c|c|c|c|c|}
\hline Source of variation & df & Grain yield & $\begin{array}{l}\text { 1000-grain } \\
\text { weight }\end{array}$ & $N$ & $\mathrm{Fe}$ & $\mathrm{Zn}$ & $\mathrm{Mn}$ & $\mathrm{Na}$ & $\mathrm{Cu}$ & $\mathrm{Ni}$ & $\mathrm{Cd}$ \\
\hline Year $(\mathrm{Y})$ & 1 & $* * *$ & $*$ & $* * *$ & $* * *$ & $* * *$ & $* * *$ & $* * *$ & $* * *$ & * & $* * *$ \\
\hline$R / Y$ & 8 & - & - & - & - & - & - & - & - & - & - \\
\hline $\mathrm{N}$ rate $(\mathrm{N})$ & 1 & $* * *$ & $* *$ & $* * *$ & $* * *$ & $* * *$ & $* * *$ & NS & $* * *$ & $* * *$ & $* *$ \\
\hline $\mathrm{Y} \times \mathrm{N}$ & 2 & NS & NS & $*$ & NS & $*$ & $* * *$ & NS & $* *$ & NS & \\
\hline Error a & 8 & - & - & - & - & - & - & - & - & - & - \\
\hline Cultivar (C) & 2 & NS & $* * *$ & $* * *$ & * & $* * *$ & $* * *$ & $* * *$ & $* * *$ & * & * \\
\hline $\mathrm{Y} \times \mathrm{C}$ & 2 & NS & $* * *$ & $* * *$ & $*$ & $*$ & $* * *$ & $* * *$ & $*$ & NS & NS \\
\hline $\mathrm{N} \times \mathrm{C}$ & 2 & NS & * & NS & NS & NS & NS & NS & NS & NS & NS \\
\hline $\mathrm{Y} \times \mathrm{N} \times \mathrm{C}$ & 2 & NS & NS & NS & NS & NS & NS & NS & NS & NS & NS \\
\hline Error b & 32 & - & - & - & - & - & - & - & - & - & - \\
\hline
\end{tabular}

$*, * *, * * *$, NS : significant at $p=0.05,0.01$, and 0.001 levels, and not significant, respectively.

Despite smaller 1000-grain weight, the high $\mathrm{N}$ fertilization rate brought about significantly higher grain yields by an average of $22.1 \%\left(1654 \mathrm{~kg} \mathrm{ha}^{-1}\right)$. These grain yield responses were consistent in both growing seasons, as indicated by the absence of growing season $\times \mathrm{N}$ rate interaction (Table 2). Compared to the low- $\mathrm{N}$ rate, the high- $\mathrm{N}$ fertilization rate resulted in even higher increase in grain $\mathrm{N}(29.2 \%$ on average). It is well-known that increasing soil $\mathrm{N}$ availability increases yield more than grain $\mathrm{N}$ until a yield maximum is reached, whereas grain $\mathrm{N}$ concentration increases if soil $N$ availability is increased further (Varga \& Svečnjak 2006). Thus, our results indicate that maximum grain yields were achieved at the high- $\mathrm{N}$ fertilization rate in a given environmental conditions. In comparison to the low-N rate, the high- $\mathrm{N}$ fertilization rate significantly increased concentrations of all trace elements except $\mathrm{Na}$ (Table 2). These increments averaged $9.2 \%$ for $\mathrm{Zn}, 13.2 \%$ for $\mathrm{Cu}, 14.0 \%$ for $\mathrm{Fe}, 15.1 \%$ for $\mathrm{Ni}$, and $19.7 \%$ for $\mathrm{Mn}$. Although increases in the concentrations of trace elements with the high- $\mathrm{N}$ fertilization rate were less than the increase in grain dry matter, grain yield positively correlated with all trace elements except $\mathrm{Na}$ (Table 5). The increased concentrations of trace elements following the high- $\mathrm{N}$ fertilization rate suggests some mechanism of enhanced nutrient uptake, but these mechanisms are still not known. Zebarth et al. (1992) reported that increased $\mathrm{N}$ application increased the average Fe concentration by $21 \%$, but had no significant effect on $\mathrm{Zn}$ and $\mathrm{Mn}$ concentrations. In China, Shi et al. (2010) found that long-term N fertilization applications in field experiments did not affect Mn concentration in winter wheat grain, but increased $\mathrm{Fe}, \mathrm{Zn}$, and Cu concentrations. They also showed that increased Fe was mostly stored in seed coat and consequently, human diet consuming flour will not benefit from increased Fe concentration in the grain because the grain fraction with increased Fe concentration will be removed by milling. In a greenhouse experiment, Kutman et al. (2011) also reported that increased N supply significantly enhanced Zn and Fe concentrations in all grain fractions. In contrast, Ryan et al. (2004) found that wheat from conventional production system had lower $\mathrm{Zn}$ and $\mathrm{Cu}$ than organic grain. Despite significant increments for trace element concentrations in both growing seasons following the application of the high-N rate (Table 3), an interaction $\mathrm{N}$ rate $\times$ growing season existed for $\mathrm{Zn}, \mathrm{Mn}$, and $\mathrm{Cu}$ in our research (Table 2). These interactions were mainly due to larger increment with the high- $\mathrm{N}$ fertilization rate for $\mathrm{Cu}$ and $\mathrm{Mn}$ concentrations in 2002 than in 2001, whereas Zn concentrations showed an opposite pattern of response (Table 3). 
Table 3. Average grain yields, 1000-grain weight, nitrogen $(\mathrm{N})$ and trace element concentrations in the grain of winter wheat crop grown at the low-N (67 kg ha-1) and high-N (194 kg ha-1) fertilization rates. Zagreb, 2001-2002.

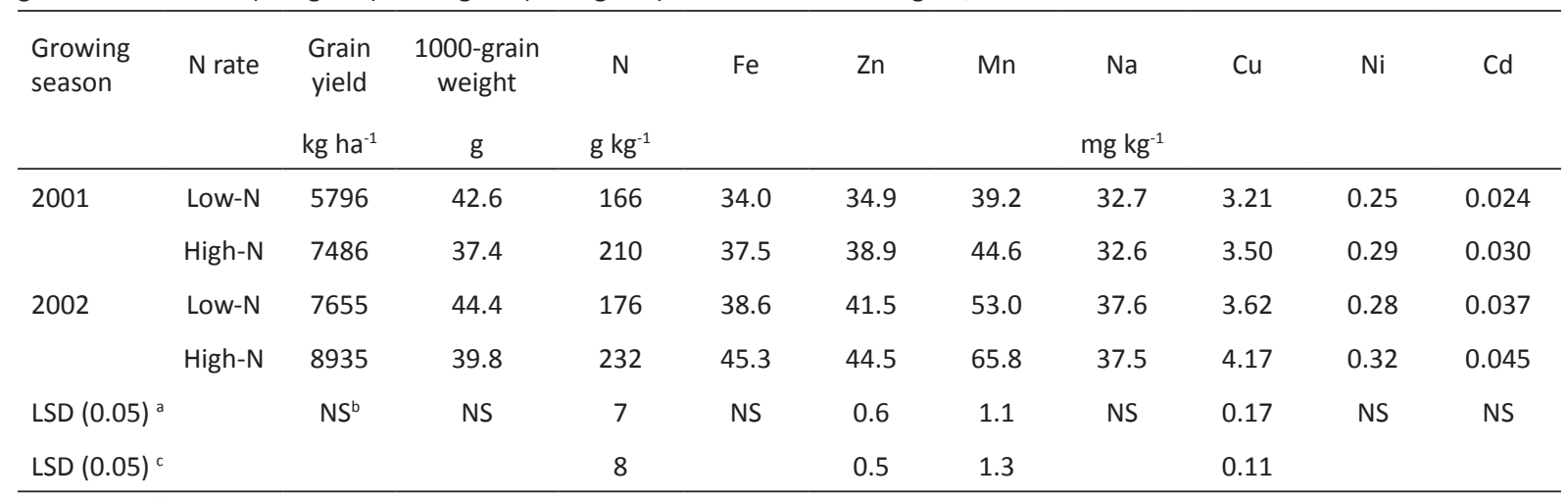

a $\mathrm{LSD}$ values for comparing means across $\mathrm{N}$ rates and growing seasons.

${ }^{\mathrm{b}}$ Not significant for $\mathrm{N}$ rate $\times$ growing season interaction at $p=0.05$.

${ }^{c}$ LSD values for comparing means within the same growing season.

Cultivars significantly differed for grain yield, 1000-grain weight and grain N concentration (Table 2). The highest grain yield produced cultivar 'Marija' even those it was characterized by the smallest 1000-grain weight (Table 3). Grain size, which is indicated by 1000-grain weight, was measured because we supposed that it could also affect trace element concentrations. However, 1000-grain weight weakly correlated with most trace elements (Table 5). Consequently, no consistent remarks could be made on the effect of grain size on trace mineral concentrations even though tested cultivars significantly differed for 1000-kernel weight (Table 4). Zebarth et al. (1992) also reported no consistent pattern for correlation between grain ash concentration and 1000-grain weight for winter wheat. In contrast, Feil and Fossati (1995) found that correlations between the values of 10 triticale cultivars showed that low 1000-grain weighs tended to be associated with increased levels of grain protein and minerals.

Table 4. Grain yields, 1000-grain weight, nitrogen (N) and trace element concentrations in the grain of winter wheat cultivars averaged over low-N and high-N fertilization rates. Zagreb, 2001-2002.

\begin{tabular}{|c|c|c|c|c|c|c|c|c|c|c|c|}
\hline $\begin{array}{l}\text { Growing } \\
\text { season }\end{array}$ & Cultivar & $\begin{array}{l}\text { Grain } \\
\text { yield }\end{array}$ & $\begin{array}{c}\text { 1000-grain } \\
\text { weight }\end{array}$ & $N$ & $\mathrm{Fe}$ & $\mathrm{Zn}$ & $\mathrm{Mn}$ & $\mathrm{Na}$ & $\mathrm{Cu}$ & $\mathrm{Ni}$ & $\mathrm{Cd}$ \\
\hline & & $\mathrm{kg} \mathrm{ha}^{-1}$ & g & $\mathrm{g} \mathrm{kg}^{-1}$ & & & & $m g \mathrm{~kg}^{-1}$ & & & \\
\hline \multirow[t]{3}{*}{2001} & Marija & 6824 & 37.2 & 197 & 36.4 & 38.0 & 44.8 & 33.8 & 3.46 & 0.29 & 0.024 \\
\hline & Renan & 6219 & 44.4 & 188 & 35.0 & 37.8 & 41.3 & 33.4 & 3.34 & 0.27 & 0.023 \\
\hline & Žitarka & 6880 & 38.4 & 178 & 35.9 & 34.8 & 39.6 & 30.6 & 3.26 & 0.26 & 0.020 \\
\hline \multirow[t]{3}{*}{2002} & Marija & 8606 & 37.4 & 204 & 40.6 & 43.1 & 59.3 & 37.7 & 3.92 & 0.30 & 0.044 \\
\hline & Renan & 8266 & 49.6 & 214 & 40.9 & 44.5 & 60.5 & 39.1 & 4.09 & 0.32 & 0.045 \\
\hline & Žitarka & 8012 & 39.3 & 195 & 44.5 & 41.4 & 58.5 & 35.8 & 3.68 & 0.28 & 0.040 \\
\hline $\operatorname{LSD}(0.05)^{\mathrm{a}}$ & & $N S^{b}$ & 2.0 & 7 & 2.6 & 0.8 & 0.1 & 0.4 & 0.20 & NS & NS \\
\hline $\operatorname{LSD}(0.05)^{\mathrm{c}}$ & & & 1.7 & 6 & 2.1 & 0.8 & 0.1 & 0.3 & 0.17 & & \\
\hline
\end{tabular}

a LSD values for comparing means across cultivars and growing seasons.

${ }^{\mathrm{b}}$ Not significant for cultivar $\times$ growing season interaction at $p=0.05$.

${ }^{c}$ LSD values for comparing means within the same growing season.

Absolutely small, but significant differences were found among tested cultivars for grain $\mathrm{N}$ and all trace elements (Table 2). McGrath (1985) reported similar results for $\mathrm{Zn}$ and $\mathrm{Cu}$, but found no difference in Fe and Mn concentrations in the grain of winter wheat varieties collected from various farms in the UK. Trace elements may differ in their distribution in wheat grain. For example, Fe is strongly concentrated in the intermediate layer (the nucellar projection) while $\mathrm{Zn}$ is concentrated in the scutellum of the wheat grain weight (Mazzolini et al. 1985). Cultivar differences in the concentrations of mineral elements in whole wheat grains may, therefore, be due to variation in kernel size and plumpness through their influence on the proportion of the endosperm to total grain weight (Peterson et al. 1983). In our research cultivar effects on trace element concentrations were remarkably uniform on both $\mathrm{N}$ fertilization rates (Table 2). However, significant growing season $\times$ cultivar interactions were found for grain $\mathrm{N}$ and most trace elements as cultivars differed in their responses and rankings across two growing seasons. 
Interaction for grain $\mathrm{N}$ was mainly due to the fact that cultivar 'Renan', which had the highest grain N content in the more favorable growing season of 2002 failed to achieve similar performance under less favorable growing conditions of 2001 (Table 4). Differences among cultivars for trace element concentrations across two growing seasons tended to follow the pattern of cultivar specific responses for grain $\mathrm{N}$, i.e. cultivar with the higher grain $\mathrm{N}$ tended to have higher concentrations for most trace elements. In the growing season of 2001 cultivar 'Marija' with the highest grain $\mathrm{N}$ also had the highest concentrations of all trace elements (Table 4). In the following growing season of 2002, such pattern of response was found for cultivar 'Renan'. Consequently, grain N positively correlated with all trace elements except $\mathrm{Na}$. These correlations with grain $\mathrm{N}$ ranged from 0.53 with $\mathrm{Zn}$ to 0.70 with $\mathrm{Cu}$ (Table 4). The causes for positive relationships between the concentration of grain $\mathrm{N}$ and mineral elements are not yet known. However, positive correlations between $\mathrm{Zn}$ and $\mathrm{N}$ or Fe and $\mathrm{N}$ are in agreement with Cakmak et al. (2010) who hypothesized that protein represents a sink for $\mathrm{Zn}$ and Fe in the grain. Moreover, some findings indicate that $\mathrm{N}$ may influence the translocation of other minerals in wheat plant. Uauy et al. (2006) discovered that delayed senescence could simultaneously decrease N, Fe, and Zn content in wheat grains.

Table 5. Correlation coefficients among grain yield (GY), 1000-kernel weight (TKW), $\mathrm{N}$ and trace mineral concentrations in the grain of winter wheat cultivars grown at the high- $\mathrm{N}$ and low- $\mathrm{N}$ fertilization rates over two growing seasons.

\begin{tabular}{|c|c|c|c|c|c|c|c|c|c|}
\hline & GY & TKW & $\mathrm{N}$ & $\mathrm{Fe}$ & $\mathrm{Zn}$ & $\mathrm{Mn}$ & $\mathrm{Na}$ & $\mathrm{Cu}$ & $\mathrm{Ni}$ \\
\hline TKW & $-0,14$ & & & & & & & & \\
\hline $\mathrm{N}$ & $0,45^{* *}$ & $-0,20$ & & & & & & & \\
\hline $\mathrm{Fe}$ & $0,48^{* *}$ & $-0,17$ & $0,53^{* *}$ & & & & & & \\
\hline $\mathrm{Zn}$ & $0,45^{* *}$ & $0,36 * *$ & $0,57^{* *}$ & $0,48^{* *}$ & & & & & \\
\hline $\mathrm{Mn}$ & $0,58^{* *}$ & 0,06 & $0,57^{* *}$ & $0,71^{* *}$ & $0,87 * *$ & & & & \\
\hline $\mathrm{Na}$ & 0,26 & $0,57^{* *}$ & 0,07 & 0,21 & $0,83 * *$ & $0,68 * *$ & & & \\
\hline $\mathrm{Cu}$ & $0,51 * *$ & 0,14 & $0,70 * *$ & $0,56^{* *}$ & $0,87^{* *}$ & $0,82 * *$ & $0,64 * *$ & & \\
\hline $\mathrm{Ni}$ & 0,23 & 0,17 & $0,61^{* *}$ & 0,29 & $0,62^{* *}$ & $0,41^{* *}$ & 0,30 & $0,58^{* *}$ & \\
\hline $\mathrm{Cd}$ & $0,42 * *$ & 0,08 & $0,66^{* *}$ & $0,61^{* *}$ & $0,89 * *$ & $0,91 * *$ & $0,64 * *$ & $0,86^{* *}$ & $0,63 * *$ \\
\hline
\end{tabular}

\section{Conclusions}

Increases in grain yields, as a result of the application of the high- $\mathrm{N}$ rate consistently produced higher concentrations of all trace elements except $\mathrm{Na}$. Trace element concentrations in wheat grain also improved under growing conditions favorable for higher yields. Absolutely small, but significant differences were found among tested cultivars for all trace elements regardless of $\mathrm{N}$ fertilization rates. However, cultivars differed in their rankings for trace element concentrations across two growing seasons and these specific responses appeared to be closely related to grain $\mathrm{N}$.

\section{References}

AACC International. 2000. Approved Methods of Analysis, 10th ed., Method 46-12.01- Kjeldahl Crude Protein. The American Association of Cereal Chemists, St. Paul, MN, USA. 3 p.

Brinch-Pedersen, H., Borg, S., Tauris, B. \& Holm, P.B. 2007. Molecular genetic approaches to increasing mineral availability and vitamin content of cereals. Journal of Cereal Science 46(3): 308-326.

Burk, R.F., \& Solomons, N.W. 1985. Trace elements and vitamins and bioavailability as related to wheat and wheat foods. The American Journal of Clinical Nutrition 41: 1091-1102.

Cakmak, I., Pfeiffer, W.H. \& McClafferty, B. 2010. Biofortification of durum wheat with zinc and iron. Cereal Chemistry 87: 10-20.

Davis, K.R., Peters, L.J., Cain, R.F., LeTourneau, D. \& McGinnis, J. 1984. Evaluation of the nutrient composition of wheat. III. Minerals. Cereal Food World 29(4): 246-248.

Dikeman, E., Pomeranz, Y. \& Lai, F.S. 1982. Minerals and protein contents in hard red winter wheat. Cereal Chemistry 59(2): $139-142$.

Feil, B. \& Fossati, D. 1995. Mineral composition of triticale grains as related to grain yield and grain protein. Crop Science 35 : $1426-1431$.

Gawalko, E.J., Garret, R.G. \& Nowicki, T.W. 2001. Trace elements in western Canadian hard red spring wheat (Triticum aestivum L.): Levels and quality assurance. The Journal of AOAC INTERNATIONAL 84: 1953-1963.

JACTS, Jarrel Ash Corporation Trace Scan 1995. Atom Scan 16/25 Plasma Spectrometer User Guide, Franklin Massachusetts, USA.120 p. 
Kutman, U.B., Yildiz, B. \& Cakmak, I. 2011. Improved nitrogen status enhances zinc and iron concentrations both in the whole grain and the endosperm fraction of wheat. Journal of Cereal Science 53: 118-125.

Mazzolini, B.A.P., Pallaghy, C.K. \& Legge, G.J.F. 1985. Quantitative microanalysis of Mn, Zn and other elements in mature wheat seed. New Phytologist 100: 483-509.

McGrath, S.P. 1985. The effects of increasing yields on the macro-and microelement concentrations and offtakes in the grain of winter wheat. Journal of the Science of Food and Agriculture 36: 1073-1083.

Milestone Moisture Cookbook, Microwave Laboratory Systems. 1996. Bergamo, Italy: Milestone. 125 p.

Musa, B. \& Abdullahi, M.S. 2013. The toxicological effects of cadmium and some other heavy metals in plants and humans. Journal of Environmental Science and Water Resources 2: 245-249.

Peterson, C.J., Johnson, V.A. \& Mattern, P.J. 1983. Evaluation of variation in mineral element concentrations in wheat flour and bran of different cultivars. Cereal Chemistry 60: 450-455.

Ryan, M.H., Derrick, J.W. \& Dan, P.R. 2004. Grain mineral concentrations and yield of wheat grown under organic and conventional management. Journal of the Science of Food and Agriculture 84: 207-216.

Santos, E.E,, Lauria, D.C. \& Porto da Silveira, C.L. 2004. Assessment of daily intake of trace elements due to consumption of foodstuffs by adult inhabitants of Rio da Janeiro city. Science of the Total Environment 327: 69-79.

SAS Institute 1997. SAS/STAT software: Changes and enhancements through release 6.12. SAS Inst., Cary, NC.

Schrenk, W.G. 1955. Chemical composition of Kansas wheat. Kansas Agricultural Experiment Station, Manhattan. 46 p.

Shi, R., Zhang, Y., Chen, X., Sun, Q., Zhang, F., Romheld, V. \& Zou, C. 2010. Influence of long-term nitrogen fertilization on micronutrient density in grain of winter wheat (Triticum aestivum L.). Journal of Cereal Science 51: 165-170.

Syltie, P.W. \& Dahnke, W.C. 1983. Mineral and protein content, test weight, and yield variations of hard red spring wheat grain as influenced by fertilization and cultivar. Qualitas Plantarum 32: 37-49.

Uauy, C., Distelfeld, A., Fahima, T., Blechl, A. \& Dubckovsky, J. 2006. A NAC gene regulating senescence improves grain protein zinc and iron content in wheat. Science 314: 1298-1301.

Varga, B., Svečnjak, Z. \& Pospišil, A. 2001. Winter wheat cultivar performance as affected by production systems in Croatia. Agronomy Journal 93: 961-966.

Varga, B. \& Svečnjak, Z. 2006. The effect of late-season urea spraying on grain yield and quality of winter wheat cultivars under low and high basal nitrogen fertilization. Field Crops Research 96: 125-132.

Welch, R.M. \& Graham, R.D. 2004. Breeding for micronutrients in staple food crops from a human nutrition perspective. Journal of Experimental Botany 55: 353-364.

Zadoks, J.C., Chang, T.T. \& Konzak, C.F. 1974. A decimal code for growth stages of cereals. Weed Research 14: 415-421.

Zebarth, B.J., Warren, C.J. \& Sheard, R.W. 1992. Influence of the rate of nitrogen fertilization on the mineral content of winter wheat in Ontario. Journal of Agricultural and Food Chemistry 40: 1528-1530. 